\title{
Production of marine trematode cercariae: a potentially overlooked path of energy flow in benthic systems
}

\author{
David W. Thieltges ${ }^{1, *}$, Xavier de Montaudouin ${ }^{2}$, Brian Fredensborg ${ }^{3}$, \\ K. Thomas Jensen ${ }^{4}$, Janet Koprivnikar ${ }^{5}$, Robert Poulin ${ }^{1}$ \\ ${ }^{1}$ Department of Zoology, University of Otago, PO Box 56, New Zealand \\ ${ }^{2}$ University Bordeaux 1-CNRS, UMR EPOC 5805, Arcachon Marine Station, 2 rue du Pr Jolyet, 33120 Arcachon, France \\ ${ }^{3}$ Department of Biology, University of Texas-Pan American, 1201 W University Drive, Edinburg, Texas 78539, USA \\ ${ }^{4}$ Department of Biological Sciences, Marine Ecology, University of Aarhus, Finlandsgade 14, 8200 Aarhus N, Denmark \\ ${ }^{5}$ Department of Biological Sciences, University of the Pacific, Stockton, California 95211, USA
}

\begin{abstract}
Parasites, in particular trematodes, are unseen but ubiquitous components of marine intertidal ecosystems. Although parasites are known to affect population dynamics and food web structure, their potential function as an unrecognized path of energy flow in these ecosystems is yet to be quantified. We use published data on rates at which trematodes produce free-swimming infective larvae (cercariae) that are released from their gastropod intermediate hosts to investigate patterns in cercarial output as a function of different variables, and to calculate the annual production of cercariae in different marine benthic systems. Across 18 trematode species, cercarial output (no. cercariae shed snail ${ }^{-1} \mathrm{~d}^{-1}$ ) ranged over 4 orders of magnitude and was positively correlated with snail host species size. While cercarial output did not correlate with latitude, it did correlate negatively with the size of cercariae, and was influenced by the type of downstream host sought by cercariae, being highest when this host was a vertebrate. Our estimates of annual cercarial production $\left(\mathrm{kJ} \mathrm{m}^{-2} \mathrm{yr}^{-1}\right)$, which take into account the density of infected snails in the habitat, were within the range of production values reported for free-living invertebrates inhabiting benthic ecosystems. These estimates would be much higher if they included all trematode species in an ecosystem, and not just single-species values. Overall, results suggest that trematode cercariae represent potentially important paths of energy flow in benthic systems as well as a potentially important food supply to benthic organisms.
\end{abstract}

KEY WORDS: Benthic production · Trematode cercariae $\cdot$ Cercarial output

\section{INTRODUCTION}

Ecologists have become increasingly aware that parasites are a hidden but omnipresent component of ecosystems (Thomas et al. 2005). Parasites do not only affect host individuals, populations and communities, but they may also play a role in ecosystem functioning (Combes 2001, Mouritsen \& Poulin 2002, Thomas et al. 2005). For example, food web analyses including and excluding parasites indicate alterations in certain food web metrics induced by parasites such as linkage density, usually considered to relate to system stability
(Thompson et al. 2005, Lafferty et al. 2006a,b). Most metazoan parasites have complex life cycles and utilise existing predator-prey links for transmission from one host to another during their life cycles (Poulin 2007). Incorporating parasites into food webs thus adds many parasite-host links and subsequently alters food web topology and dynamics (Lafferty et al. 2008).

Another potential role for parasites in food webs is that they may serve as prey for other organisms or contribute to the flow of matter and energy in some other way. For example, parasites of infected prey may be an additional food resource for predators 
when the latter are unsuitable hosts for the parasites. While this contribution of parasites may be substantial, especially at high infection levels, the actual magnitude of this additional food source is unknown. Even more likely, free-living stages of parasites may serve as prey for other non-host organisms. Most parasites with complex life cycles include free-living stages for transmission from one host to another (Poulin 2007), and a range of studies from terrestrial, freshwater and marine systems suggest that these free-living stages are preyed upon by a variety of organisms (see Thieltges et al. 2008a). The vast majority of these infective stages do not successfully reach a suitable host, and if they are not ingested by non-host predators, they become food for bacterial decomposers. As most free-living stages of parasites are produced in high numbers they may constitute a substantial path of energy flow in ecosystems.

In coastal benthic ecosystems, the dominant macroparasite group consists of the digenean trematodes, which typically have complex life cycles involving 3 different hosts (Lauckner 1980, Mouritsen \& Poulin 2002). First intermediate hosts are mainly gastropods, and a range of invertebrates and vertebrates serves as second intermediate hosts; vertebrates act as definitive hosts. Trematodes produce free-living stages to transmit between definitive and first and between first and second intermediate hosts. In the latter case, the infective stages, called cercariae, are asexually produced in the gastropod first intermediate hosts and released in large numbers into the environment. Cercariae basically represent lecitotrophic larvae with glycogen storage and hence are very nutritious (Xu et al. 1994, Fried et al. 1998). Recent studies indicate that marine cercariae are consumed by a variety of benthic non-host organisms ranging from anemones, bivalves and crustaceans to juvenile fish (Mouritsen \& Poulin 2003, Thieltges et al. 2008b, Kaplan et al. in press). While benthic systems are well studied with respect to production of free-living species (see Cusson \& Bourget 2005), little is known about the production of cercariae. A recent study in 3 estuaries on the Pacific Coast of California and Baja California suggests annual cercarial production to be greater than bird biomass in these systems (Kuris et al. 2008). However, for other systems the production of cercariae is unknown.

For many marine trematode species, experimental data are available on the rates at which cercariae are shed from snail hosts. In general, the number of cercariae shed into the environment strongly depends on the ambient temperature (Poulin 2006). This effect of temperature may underlie an influence of latitude, with lower cercarial output to be expected at higher latitudes. In addition, host size is, in general, positively correlated with shedding rates as larger hosts provide more space and energy resources for the development of cercariae (Poulin 2006). The effect of snail size on cercarial shedding rates is not only present within a snail species but also among snail host species of different size (Poulin 2006). Other factors that might affect shedding rates are the size of cercariae, the size of the cercariae-producing structures (sporocysts or rediae) within the snail, and the type of target host coming next in the life cycle of the parasite (downstream host). With increasing size of the cercariae, we expect a decrease in shedding rates as the result of a trade-off between numbers and size: the production of larger cercariae is more costly given that resources for production are limited (Loker 1983). Similarly, we can expect a lower cercarial output with increasing size of the cercariae-producing structures as both space and energy resources are limited. The type of downstream host should also affect shedding rates (McCarthy et al. 2002). We expect the highest shedding rates in cases where vertebrates are the next hosts in a parasite's life cycle as vertebrates are rare and highly mobile, and selection should have favoured high output rates to achieve successful transmission. These predictions are also suggested by similar patterns in trematode biomass in snail hosts, as cercarial output is probably correlated with the parasite biomass in the snail (Hechinger et al. 2008).

The total amount of cercarial stages shed into coastal systems depends not only on the shedding rate of cercariae but also on the trematode infection levels and the abundance of the snail hosts. Again, relevant data are available for some marine cercariae and allow the calculation of the annual production of cercariae in coastal systems. This annual production may follow the same latitudinal trends observed in free-living marine benthic species, and may also show differences among habitat types (Ricciardi \& Bourget 1999, Cusson \& Bourget 2005). Cercarial production may represent a previously unrecognized but substantial path of energy flow and a substantial input of food resources for numerous organisms into marine ecosystems, just as parasites in general and trematodes in particular represent a substantial proportion of the standing crop biomass in these systems (see Kuris et al. 2008).

In this study, we use published data to (1) investigate patterns in cercarial output in terms of differences in shedding rates dependent on snail host species size, latitude, size of cercariae, size of cercariae-producing stages (sporocysts or rediae) and type of downstream host, and (2) calculate the annual production of cercariae in different marine benthic systems depending on host species size, latitude and habitat. Our calculations allow us to estimate the magnitude of cercarial production and to investigate factors influencing these production patterns. 


\section{MATERIALS AND METHODS}

Patterns in cercarial output. We searched literature databases and our own reprint collections for studies that investigated shedding rates of trematode cercariae from marine gastropod hosts. We only used studies that maintained replicate snails in experimental conditions at 2 or more constant temperatures for several days, and that reported counts of the numbers of cercariae shed per snail per unit time. To standardise the data, we converted all measurements into daily output rates (no. cercariae shed snail ${ }^{-1} \mathrm{~d}^{-1}$ ). We chose $20^{\circ} \mathrm{C}$ as a focal point for comparisons as it is well within the natural temperature range experienced by all parasite species used in our analysis. In cases where no data were given for $20^{\circ} \mathrm{C}$, we extrapolated from measurements taken just below and above $20^{\circ} \mathrm{C}$.

In addition, we obtained data for 5 variables that may influence cercarial output: (1) the latitude at which the snails for experiments had been collected; (2) the mean shell length of the different snail host species obtained from the original publications or from molluscan databases; (3) the volume of a single cercaria of each trematode species as calculated by using measurements from published species descriptions (body length and width, and tail length and width), assuming a cylindrical shape of body and tail; (4) length measurements of rediae or sporocysts obtained from the literature; and (5) the nature of the downstream hosts (invertebrates, vertebrates, or free-living metacercariae for species that encyst on any substrate) as indicated in literature on the life-cycles of the species.

Annual cercarial production in different systems. We searched for systems where data on infection levels in the snail hosts (mean prevalence, i.e. the proportion of infected individuals in the total sample) and snail host density were available in addition to data on cercarial output. This was only the case for a subset of the species used for the calculations above. In addition, we included some sites where shedding rates were taken at temperatures other than $20^{\circ} \mathrm{C}$ but where infection levels and host densities were available from the same systems. We used these data to calculate the daily cercarial output and the annual cercarial production in the different systems.

Daily cercarial output (DO) $\left(\mathrm{m}^{-2} \mathrm{~d}^{-1}\right)$ was calculated as follows:

$$
\mathrm{DO}=d p s / 2
$$

where $d$ is the density of host snails (ind. $\mathrm{m}^{-2}$ ), $p$ is the proportion of infected snails and $s$ is the cercarial shedding rate at approximately $20^{\circ} \mathrm{C}$ (no. cercariae snail ${ }^{-1}$ $\mathrm{d}^{-1}$ ). In the few cases where densities of infected individuals were given in the literature we multiplied the density values with $s$ divided by 2 to get DO. As all available data were from intertidal systems, we divided the shedding rates by 2 to accommodate for usually diurnal tidal rhythms. Snails shed cercariae mainly when they are immersed (Galaktionov \& Dobrovolskij 2003), and we assumed a mean inundation time of $12 \mathrm{~h} \mathrm{~d}^{-1}$.

Using the daily cercarial output (no. cercariae $\mathrm{m}^{-2} \mathrm{~d}^{-1}$ ) we calculated the annual output of cercariae. Marine cercariae at low latitudes are constantly shed (Appleton 1983a, Kuris et al. 2008) while cercariae at higher latitudes have a restricted shedding period during the warmer summer months (Thieltges \& Rick 2006). As the sites group into 3 distinct latitudinal bands $\left(30-35^{\circ}\right.$, around $45^{\circ}$ and around $55^{\circ}$; Table 1$)$, we assumed a shedding period of $360 \mathrm{~d}$ for cercariae from $30-35^{\circ}, 180 \mathrm{~d}$ for $45^{\circ}$ and $90 \mathrm{~d}$ for $55^{\circ}$. Preliminary analyses indicate that the results are not overly sensitive to these choices of numbers, thus the results are robust independently of the above assumptions. The annual output ( $\mathrm{AO}$, no. cercariae $\mathrm{m}^{-2} \mathrm{yr}^{-1}$ ) was calculated accordingly as $\mathrm{AO}=\mathrm{DO}(360$ ) (or 180 or 90). We used the volumes of single cercariae (see above) to convert AO into total volume of cercariae produced $(\mathrm{ml}$ cercariae $\mathrm{m}^{-2} \mathrm{yr}^{-1}$ ). By applying commonly used conversion factors for zooplankton for converting displacement volume into carbon production $(1 \mathrm{ml}$ displacement volume $=96 \mathrm{mg} \mathrm{C}$; Cushing et al. 1958, Postel et al. 2000) we calculated the annual cercarial production of carbon ( $\mathrm{g} \mathrm{C} \mathrm{m}^{-2} \mathrm{yr}^{-1}$ ). To compare this annual carbon production with data on macroinvertebrate production in marine benthic habitats from a comprehensive review (Cusson \& Bourget 2005), we converted our carbon values into $\mathrm{kJ} \mathrm{m}^{-2} \mathrm{yr}^{-1}$ using the appropriate conversion factor from the literature $(1 \mathrm{mg}=45.7 \mathrm{~J}$; Salonen et al. 1976, Brey 2001). We calculated the arithmetic mean of annual cercarial production and compared the value with values for free-living species from data presented in Cusson \& Bourget (2005, their Table 4, back-transformed from log-scale).

Statistical analyses. We used linear regressions to investigate relationships between daily cercarial output and annual production (both ln-transformed) and snail host species size. In cases where we found a significant relationship we used residuals from the regression to correct for host species size as a confounding factor. Further linear regression analyses were then conducted using these residuals. Differences in daily cercarial output among types of downstream hosts were tested with a 1-way ANOVA using cercarial output (corrected for host species size) as the dependent variable. For a subsequent post-hoc test we used Tukey's HSD test for unbalanced data sets. Differences in annual cercarial production between the 2 habitats (rocky and sedimentary shores) were tested with a $t$-test using annual production (ln-transformed) as the dependent variable. In all analyses of variance 
Table 1. Daily cercarial output (DO) (no. cercariae $\mathrm{m}^{-2} \mathrm{~d}^{-1}$ ) and annual cercarial production (AP) ( $\mathrm{kJ} \mathrm{m}^{-2} \mathrm{yr}^{-1}$ ) of trematodes in different coastal systems calculated based on literature data (see Table A2, www.int-res.com/articles/suppl/m372p147_app.pdf). For details of the calculation see text. Additional parameters for each system are given: latitude and type of habitat (soft [S] versus hard $[\mathrm{H}]$ substrate)

\begin{tabular}{|c|c|c|c|c|c|c|}
\hline Site & Parasite & Host & Latitude & $\begin{array}{l}\text { Habitat } \\
\text { type }\end{array}$ & $\begin{array}{l}\mathrm{DO}(\text { no. } \\
\left.\mathrm{m}^{-2} \mathrm{~d}^{-1}\right)\end{array}$ & $\begin{array}{l}\text { AP }(\mathrm{kJ} \\
\left.\mathrm{m}^{-2} \mathrm{yr}^{-1}\right)\end{array}$ \\
\hline \multirow{3}{*}{$\begin{array}{l}\text { List tidal basin, } \\
\text { Wadden Sea, } \\
\text { Germany }\end{array}$} & Himasthla elongata & Littorina littorea & $55^{\circ} 01^{\prime} \mathrm{N}$ & $\mathrm{S}$ & 1064.5 & 10.4 \\
\hline & Renicola roscovita & Littorina littorea & $55^{\circ} 01^{\prime} \mathrm{N}$ & $\mathrm{S}$ & 1653 & 1 \\
\hline & Maritrema subdolum & Hydrobia ulvae & $54^{\circ} 56^{\prime} \mathrm{N}$ & $\mathrm{S}$ & 74721.5 & 7 \\
\hline $\begin{array}{l}\text { Wismar Bight, } \\
\text { Baltic Sea, Germany }\end{array}$ & Maritrema subdolum & Hydrobia ventrosa & $54^{\circ} 00^{\prime} \mathrm{N}$ & $\mathrm{S}$ & 24375 & 2.3 \\
\hline Cardigan Bay, Wales & Parorchis acanthus & Nucella lapillus & $52^{\circ} 25^{\prime} \mathrm{N}$ & $\mathrm{H}$ & 221.18 & 7.8 \\
\hline $\begin{array}{l}\text { County Antrim, } \\
\text { Northern Ireland }\end{array}$ & $\begin{array}{l}\text { Microphallus simils } \\
\text { Maritrema arenaria }\end{array}$ & $\begin{array}{l}\text { Littorina saxatilis } \\
\text { Littorina saxatilis }\end{array}$ & $\begin{array}{l}54^{\circ} 27^{\prime} \mathrm{N} \\
54^{\circ} 27^{\prime} \mathrm{N}\end{array}$ & $\begin{array}{l}\mathrm{H} \\
\mathrm{H}\end{array}$ & $\begin{array}{c}1887.5 \\
99.5\end{array}$ & $\begin{array}{c}0.3 \\
0.005\end{array}$ \\
\hline Arcachon Bay, France & $\begin{array}{l}\text { Himasthla continua } \\
\text { Haploporidae species } \\
\text { Cryptocotyle concava }\end{array}$ & $\begin{array}{l}\text { Hydrobia ulvae } \\
\text { Hydrobia ulvae } \\
\text { Hydrobia ulvae }\end{array}$ & $\begin{array}{l}44^{\circ} 39^{\prime} \mathrm{N} \\
44^{\circ} 39^{\prime} \mathrm{N} \\
44^{\circ} 39^{\prime} \mathrm{N}\end{array}$ & $\begin{array}{l}\mathrm{S} \\
\mathrm{S} \\
\mathrm{S}\end{array}$ & $\begin{array}{c}5 \\
475.5 \\
7585.5\end{array}$ & $\begin{array}{l}0.04 \\
3.8 \\
4.7\end{array}$ \\
\hline $\begin{array}{l}\text { Carpinteria Salt Marsh, } \\
\text { California, USA }\end{array}$ & Himasthla rhigedana & Cerithidea californica & $34^{\circ} 24^{\prime} \mathrm{N}$ & $\mathrm{S}$ & 7360 & 490.4 \\
\hline $\begin{array}{l}\text { Eastport and Roque } \\
\text { Bluffs, Maine, USA }\end{array}$ & Cryptocotyle lingua & Littorina littorea & $44^{\circ} 46^{\prime} \mathrm{N}$ & $\mathrm{H}$ & 11457 & 4.7 \\
\hline \multirow[t]{3}{*}{$\begin{array}{l}\text { Swan Estuary, } \\
\text { Australia }\end{array}$} & Stictodora lari & $\begin{array}{l}\text { Velacumantus (Batillaria) } \\
\text { australis }\end{array}$ & $32^{\circ} 00^{\prime} \mathrm{S}$ & $\mathrm{S}$ & 103326 & 265.3 \\
\hline & Austrobilharzia terrigalensis & $\begin{array}{l}\text { Velacumantus (Batillaria) } \\
\text { australis }\end{array}$ & $32^{\circ} 00^{\prime} \mathrm{S}$ & $\mathrm{S}$ & 568 & 0.88 \\
\hline & Philophthalmus burili & $\begin{array}{l}\text { Velacumantus (Batillaria) } \\
\text { australis }\end{array}$ & $32^{\circ} 00^{\prime} \mathrm{S}$ & $\mathrm{S}$ & 457.2 & 10.7 \\
\hline \multirow{3}{*}{$\begin{array}{l}\text { Otago Harbour, } \\
\text { New Zealand }\end{array}$} & Maritrema novozealandensis & Zeacumantus subcarinatus & $45^{\circ} 50^{\prime} \mathrm{S}$ & $\mathrm{S}$ & 8307 & 0.5 \\
\hline & Acanthoparyphium sp. & Zeacumantus subcarinatus & $45^{\circ} 50^{\prime} \mathrm{S}$ & $\mathrm{S}$ & 742 & 4.4 \\
\hline & Philophtalmus sp. & Zeacumantus subcarinatus & $45^{\circ} 50^{\prime} \mathrm{S}$ & $\mathrm{S}$ & 280 & 3.2 \\
\hline
\end{tabular}

we used type III SS to account for unbalanced sample sizes (Shaw \& Mitchell-Olds 1993). Significance level was set at 0.05 in all analyses.

\section{RESULTS}

\section{Patterns in daily cercarial output}

We obtained experimental data on cercarial output for 18 trematode species from 7 families (Table A1, available as MEPS Supplementary Material at www. int-res.com/ articles/suppl/m372p147_app.pdf). Some of the trematode species shared the same host species. One trematode species, Parorchis acanthus, was studied in 2 different snail host species, Cerithidea californica and Nucella lapillus. Daily cercarial output ranged over 4 orders of magnitude, from less than 10 to over 19000 cercariae infected snail ${ }^{-1} \mathrm{~d}^{-1}$. It was positively correlated with snail host species size $\left(\mathrm{R}^{2}=0.43, \mathrm{p}=0.003\right)$ (Fig. 1$)$. While latitude showed no correlation with daily cercarial output (corrected for host size, $\mathrm{p}=0.5$ ), the latter was negatively correlated with cercarial volume and size of the cercariae producing stages (Fig. 2a,b). Snails produced fewer cercariae (corrected for host size) when cercariae were large $\left(R^{2}=0.29, p=0.02\right)$, and larger rediae pro-

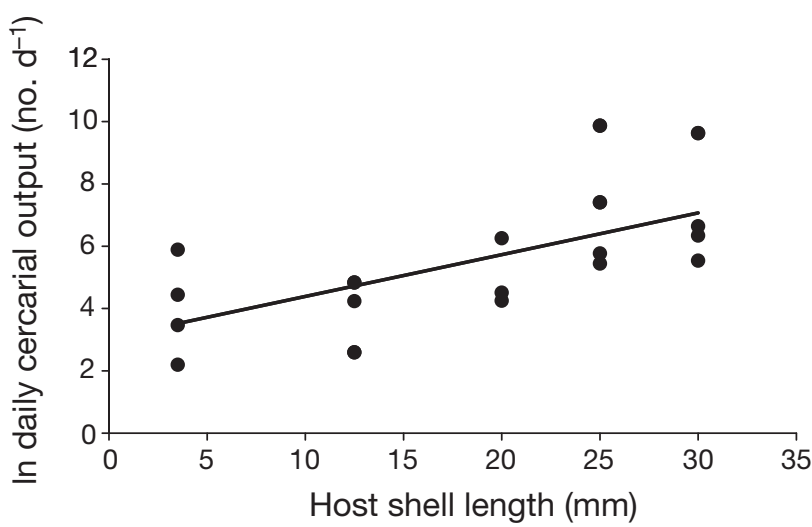

Fig. 1. Daily cercarial output (ln no. cercariae snail ${ }^{-1} \mathrm{~d}^{-1}$ ) of marine cercariae as a function of snail host species size $(\mathrm{mm})$. The line represents the best linear fit $(y=0.1342 x+3.0469)$

duced fewer cercariae compared to smaller ones $\left(\mathrm{R}^{2}=\right.$ 0.58, $\mathrm{p}=0.01$ ) (Fig. 2c). The latter pattern seemed to appear in sporocysts too (Fig. 2c), but the relationship was not significant, probably due to low sample size $(p=0.31)$. Cercarial production differed significantly among trematodes with different types of downstream hosts $\left(F_{2,15}=5.22, \mathrm{p}=0.019\right)$. Cercariae infecting vertebrate hosts showed the highest daily cercarial production (corrected for host size) while cercariae that encyst 

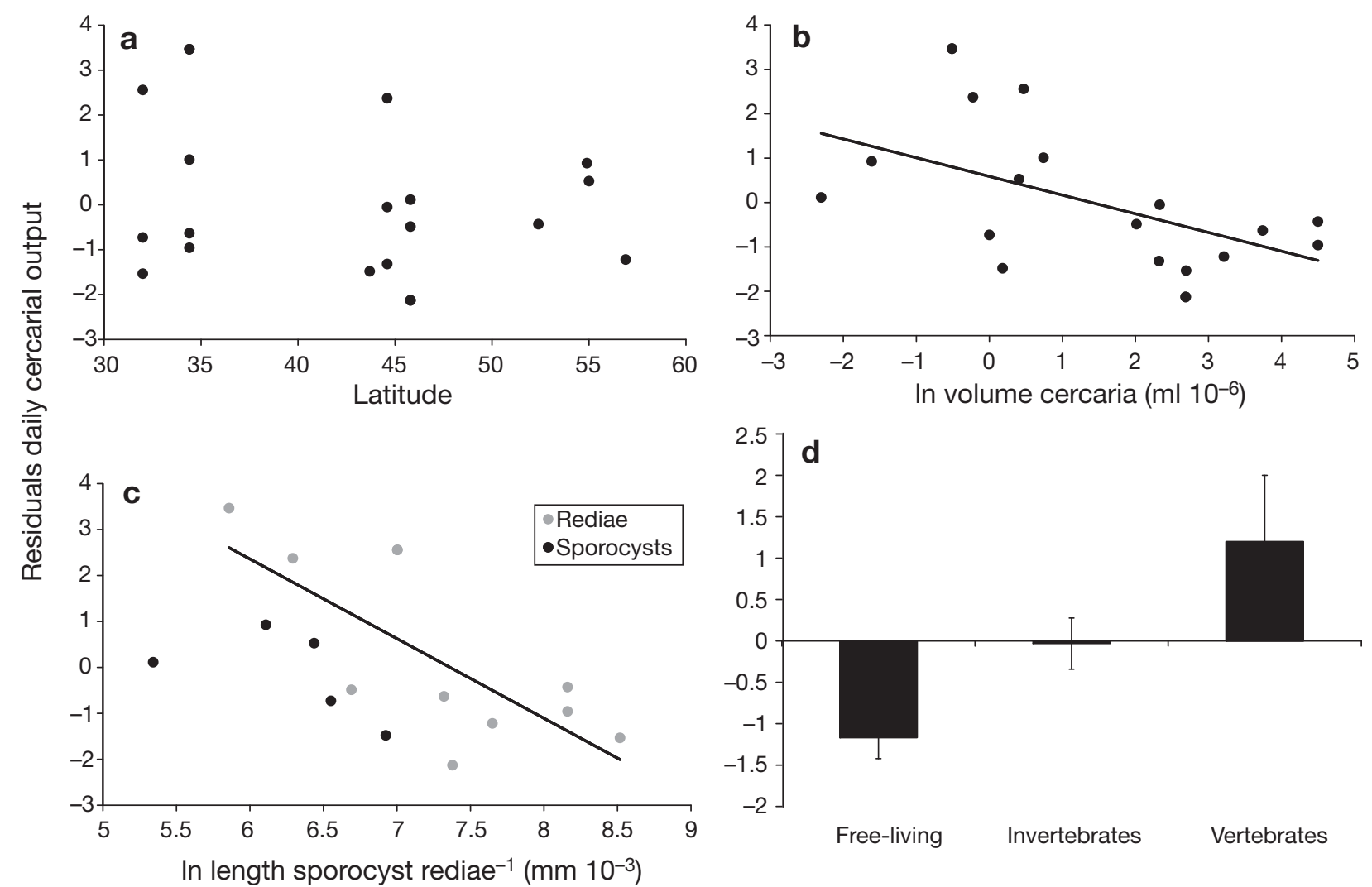

Fig. 2. Daily cercarial output corrected for snail host species size (residuals from the regression in Fig. 1) as a function of: (a) latitude; (b) ln volume of a single cercaria $\left(10^{-6} \mathrm{ml}\right) ;$ (c) ln length of sporocysts or rediae $\left(10^{-3} \mathrm{~mm}\right)$; and (d) type of downstream host $($ mean $\pm \mathrm{SE}$ ). Lines represent the best linear fit (ln volume single cercariae: $y=-0.421 x+0.5883$; ln length of rediae: $y=-1.7338 x+12.762)$

on substrate and remain free-living in the environment showed the lowest daily production (Fig. 2d). However, this difference in daily cercarial production was only significant between encysting, free-living cercariae and cercariae infecting vertebrate hosts (Tukey's HSD, p = 0.015 ; free-living vs. invertebrates: $p=0.30$; invertebrates vs. vertebrates: $\mathrm{p}=0.24$ ).

\section{Annual cercarial production in different systems}

We obtained data for 18 trematode species from 9 systems (Tables 1 \& A2). The annual production of cercariae increased with snail host size (Fig. 3), but this relationship was not significant $(p=0.051)$. A negative correlation between latitude and annual cercarial production was also not significant ( $\mathrm{p}=0.053$ ) (Fig. 4). There was also no significant difference in annual cercarial production between habitats $\left(F_{1,16}=2.3, \mathrm{p}=\right.$ $0.15)$ although mean production was almost 18 times higher on soft $\left(57.5 \pm 38.1 \mathrm{~kJ} \mathrm{~m}^{-2} \mathrm{yr}^{-1}, \mathrm{n}=14\right)$ than on hard substrate $\left(3.2 \pm 1.9 \mathrm{~kJ} \mathrm{~m}^{-2} \mathrm{yr}^{-1}, \mathrm{n}=4\right)$.

The mean $( \pm \mathrm{SE}$ ) daily output of cercariae per species was $16904 \pm 11373$ cercariae $\mathrm{m}^{-2} \mathrm{~d}^{-1}$. Mean annual

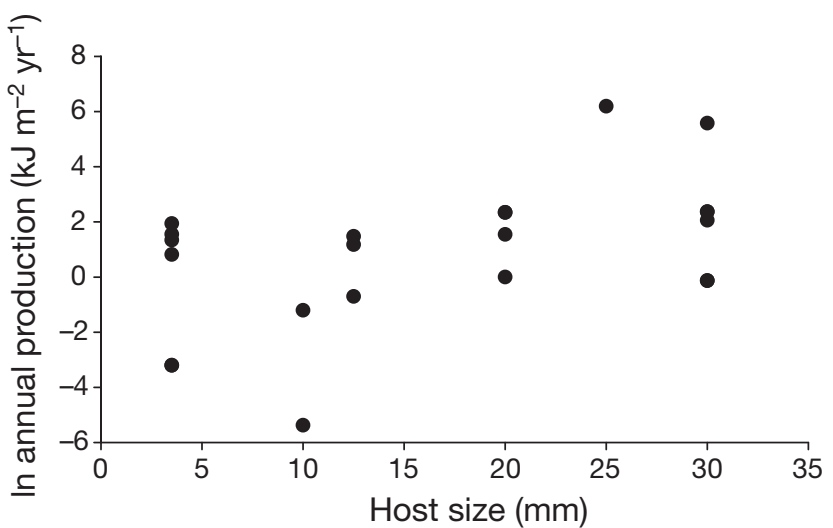

Fig. 3. Annual cercarial production $\left(\mathrm{ln} \mathrm{kJ} \mathrm{m}^{-2} \mathrm{yr}^{-1}\right)$ in different trematode-snail systems as a function of snail host species size $(\mathrm{mm})$

production per trematode species was $45.4 \pm 29.9 \mathrm{~kJ}$ $\mathrm{m}^{-2} \mathrm{yr}^{-1}$, with 2 high (Himasthla rhigedana and Stictodora lari, see Table 1) and 2 low values (Maritrema arenaria and Himasthla continua) influencing this average. Excluding these 4 extreme values, mean production was $4.4 \pm 0.9 \mathrm{~kJ} \mathrm{~m}^{-2} \mathrm{yr}^{-1}$ (Fig. 5). Literature 


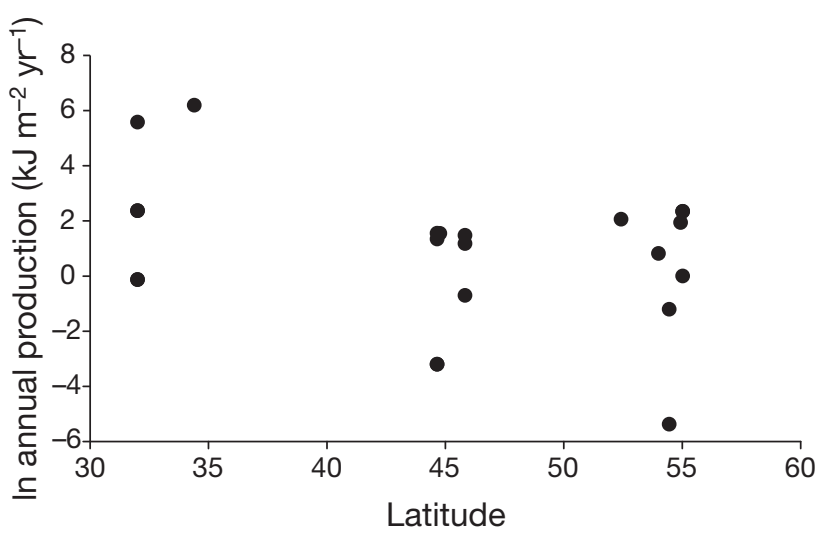

Fig. 4. Annual cercarial production ( $\left(\mathrm{kJ} \mathrm{m}^{-2} \mathrm{yr}^{-1}\right)$ in different trematode-snail systems as a function of latitude

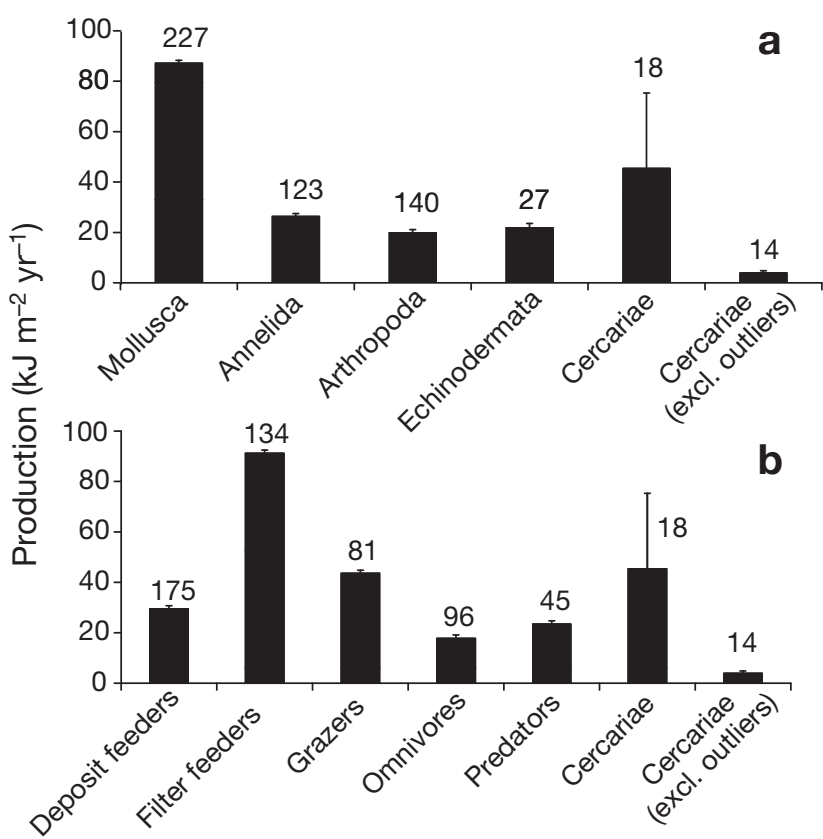

Fig. 5. Mean annual production $\left(\mathrm{kJ} \mathrm{m}^{-2} \mathrm{yr}^{-1}\right)$ (+ SE) of (a) taxonomic groups and (b) functional guilds of marine benthic invertebrates and cercariae. Data on cercariae from the present study, all other data from Cusson \& Bourget (2005). Numbers above bars denote the numbers of values used to calculate means

values from free-living species ranged from 17.8 to $91.2 \mathrm{~kJ} \mathrm{~m}^{-2} \mathrm{yr}^{-1}$ (Cusson \& Bourget 2005) (Fig. 5).

\section{DISCUSSION}

Although varying in magnitude, the mean annual production of cercariae was comparable to the annual production of taxonomic groups and functional guilds of free-living macroinvertebrates in marine benthic habitats (Cusson \& Bourget 2005) (Fig. 5). All single cercarial production values were within the range of the annual production of free-living macroinvertebrates reported by Cusson \& Bourget (2005). However, the annual production of 4 cercariae species was clearly higher (490 and $\left.265 \mathrm{~kJ} \mathrm{~m}^{-2} \mathrm{yr}^{-1}\right)$ or lower $(0.005$ and $0.04 \mathrm{~kJ} \mathrm{~m}^{-2} \mathrm{yr}^{-1}$ ) than the average, and calculating the mean annual cercarial production without these outliers resulted in a value 4 to 21 times lower than that of free-living species (Fig. 5). As our calculations are based on cercariae of single parasite species, they are a rather conservative estimate of the actual cercarial production in a particular system. All snail hosts used for the calculations are parasitized by several parasite species (though double infections are generally uncommon). For example, at least 34 species have been described from Hydrobia ulvae (Deblock 1978, 1980), 15 from Cerithidea californica (Huspeni \& Lafferty 2004), 11 from Littorina littorea (Lauckner 1980), 5 from Zeacumantus subcarinatus (Fredensborg et al. 2006) and 3 from Velacumantus (Batillaria) australis (Appleton 1983b). Hence, the combined cercarial production of co-occurring parasites will be much higher than the values we calculated. In addition, at most sites there are many sympatric snail species, each host to a different suite of trematode species, thus adding to the total annual production of cercariae at a site.

Our calculations of annual cercarial production are based on conservative estimates using mean parasite prevalence and host density values. Spatial heterogeneity in infection levels of gastropod hosts is usually high in coastal systems (Curtis \& Hurd 1983, Poulin \& Mouritsen 2003, Fredensborg et al. 2006), and locally much higher infection levels have been observed in most of the species included in the analysis (e.g. Lauckner 1980, Appleton 1983b, Fredensborg et al. 2006). The same is true for host densities. Spatial heterogeneity in gastropod distribution and abundance is a well studied phenomenon in coastal ecosystems (Raffaelli \& Hawkins 1996, Nybakken \& Bertness 2005) and cercarial production will be elevated at sites with high host densities assuming that the proportions of infected snails within the host population are the same. According to the formula DO $=d p s / 2$ (see 'Materials and methods'), a doubling of snail density will result in twice as many cercariae shed into the environment on a daily basis. Similarly, if prevalence increases by a factor of 2, this will result in a doubling of daily cercarial output. Hence, cercarial production is likely to be much higher at sites with high infection levels and high host densities than the values we calculated. Production will also be higher at higher temperatures than the approximately $20^{\circ} \mathrm{C}$ we chose for comparison, as cercarial output is strongly temperature-dependent (Poulin 2006). At times, temperatures may well exceed $20^{\circ} \mathrm{C}$ in all systems included in the analysis, thus pro- 
duction will temporarily be higher than the values we calculated. In general, cercarial production can be expected to be highest during the warm summer months.

The fate of the large amount of cercariae shed into marine systems is not known. All we know is that the vast majority of these infective stages do not successfully reach a suitable host. Recent studies indicate that marine cercariae are consumed by a variety of benthic non-host organisms (Mouritsen \& Poulin 2003, Thieltges et al. 2008b, Kaplan et al. in press). The large production of cercariae may thus provide benthic organisms with a food source that has so far not been recognized. Cercariae should be a valuable food source as they are basically lecitotrophic larvae with glycogen rich storage; hence they are very nutritious (Xu et al. 1994, Fried et al. 1998). Their size is within the range of micro and smaller mesoplankton and thus within the size range of prey of filter feeders and small benthic predators (Køie 1975, Newell 1979). It is not known to what extent benthic organisms actually make use of this resource, but field investigations on juvenile fish suggest that cercariae actually contribute to their diet (Kaplan et al. in press). Even if cercariae are not consumed by benthic invertebrates, they add to the flow of energy by entering the bacterial decomposition cycle as detritus. Further studies are needed to evaluate the relevance and magnitude of cercariae as a food resource for marine benthic organisms and their general contribution to marine benthic production.

We could not detect an effect of snail host species on annual cercarial production, probably because of confounding effects of infection levels and host densities on production. It is also possible that our low sample size additionally confounded any patterns, particularly as productivity patterns might differ between the northern and the southern hemisphere (Cusson \& Bourget 2005). However, the marginal significance and the graphical depiction of the data (Figs. $3 \& 4$ ) suggest that there might be a trend nevertheless. Increasing sample size and direct measurements of productivity in the field might be an approach to further investigate the matter. In contrast to annual cercarial production, the daily output of cercariae was clearly influenced by several factors. In line with other studies (Poulin 2006), larger snail species produced a higher daily output, probably because they provide more space and a larger energy resource for the development of cercariae. This has an analogy in the positive correlation between offspring production and gastropod size (Fretter \& Graham 1994). A trade-off between space and energetic constraints and cercarial output may also explain the observation that an increase in cercarial volume resulted in a decrease in daily cercarial output. Interestingly, this is in contrast to trade-offs in schistosomes, where cercarial production increases with increasing length of cercariae (Loker 1983). A trade-off may also explain the decrease in output with an increase in size of rediae and sporocysts, although this relationship was not significant with sporocysts. The type of downstream host also affects cercarial output with parasites using vertebrates as downstream hosts shedding more cercariae than parasites using invertebrates as downstream hosts or free-living metacercariae. This probably has a simple evolutionary explanation: natural selection would favour the production of many small cercariae if the target host is mobile and at low density. A similar trade-off has been observed in parasitic copepods where species infecting fish have higher output of infective eggs than species infecting invertebrate downstream hosts (Poulin 1995). All this suggests that cercarial output is determined by space- and energymediated trade-offs and by natural selection for optimised transmission to downstream hosts.

In conclusion, the annual production of cercariae is within the range of the production of free-living benthic invertebrates and this has important implications. First, cercariae may constitute an underrepresented path of energy flow in benthic systems. Field measurements will be necessary to determine the actual magnitude of the cercarial compartment in marine food webs, which may be substantial (Kuris et al. 2008). Second, as there are indications that cercariae are consumed by a variety of non-host organisms, cercariae may be a substantial but unrecognized food supply to benthic organisms as also indicated by food web analyses integrating cercariae as potential prey items for free-living species (Lafferty et al. 2006a,b). However, this food supply might be compensatory rather than additive. Trematodes partially or totally castrate their snail hosts, and thus the production of cercariae may simply substitute the normal host offspring production (Mouritsen \& Jensen 1994). It is unclear if cercarial production is actually equal to or higher than the production of offspring. Comparing literature data on the numbers of eggs produced by various snail species with the daily cercarial output values from Table 1 suggests similar levels of production, but also indicates cases where cercarial production seems to be much higher (Barnes 1990, Buschbaum \& Reise 1999, Fredensborg et al. 2005). However, these comparisons are only based on the numbers of eggs and cercariae produced by the snails and do not take into account potential differences in size between eggs and cercariae and their potentially differing energetic value. More detailed studies, ideally directly comparing the production rates of eggs and cercariae in snail hosts, are needed to decide if cercarial production is additive or compensatory in terms of food supply to benthic com- 
munities. It will also be necessary to investigate the actual consumption rates of cercariae and snail eggs by potential predators as the relevance of cercarial supply in benthic systems may differ among predator species. While cercariae-consuming animals may benefit from parasites, those consuming primarily snail offspring (eggs or larvae) may have less food available if a high proportion of snails is infected. Again, field observations accompanied by laboratory feeding experiments will be needed to estimate the relevance and magnitude of cercarial production in benthic systems.

Acknowledgements. We thank the members of Otago University's Ecological Parasitology Laboratory for comments on the manuscript. Thanks to J. D. Fish and K. Reise for literature suggestions. D.W.T. acknowledges support by a fellowship from the Deutsche Forschungsgemeinschaft (DFG) (Th 1361/ 1-1). We thank 3 anonymous reviewers for their valuable comments.

\section{LITERATURE CITED}

Appleton CC (1983a) Studies on Austrobilharzia terrigalensis (Trematoda: Schistosomatidae) in the Swan Estuary, Western Australia: observations on the biology of the cercariae. Int J Parasitol 13:239-247

Appleton CC (1983b) Studies on Austrobilharzia terrigalensis (Trematoda: Schistosomatidae) in the Swan Estuary, Western Australia: frequency of infection in the intermediate host population. Int J Parasitol 13:51-60

Barnes RSK (1990) Reproductive strategies in contrasting populations of the coastal gastropod Hydrobia ulvae. 2. Longevity and life-time egg production. J Exp Mar Biol Ecol 138:183-200

Brey T (2001) Population dynamics in benthic invertebrates: a virtual handbook. Version 01.2. Alfred Wegener Institute for Polar and Marine Research, Bremerhaven, available at www.awi-bremerhaven.de/Benthic/Ecosystem/FoodWeb/ Handbook/main.html

Buschbaum C, Reise K (1999) Effects of barnacle epibionts on the periwinkle Littorina littorea (L.). Helgol Mar Res 53: 56-61

Combes C (2001) Parasitism: the ecology and evolution of intimate interactions. University of Chicago Press, Chicago, IL

Curtis LA, Hurd LE (1983) Age, sex and parasites: spatial heterogeneity in a sandflat population of Ilyanassa obsoleta. Ecology 64:819-828

Cushing DH, Humprey GH, Banse K, Laevastu T (1958) Report of the committee on terms and equivalents. Rapp P-V Reun Cons Int Expl Mer 144:15-16

Cusson M, Bourget E (2005) Global patterns of macroinvertebrate production in marine benthic habitats. Mar Ecol Prog Ser 297:1-14

Deblock S (1978) Distribution géographique des cercaires parasites des mollusques du genre Hydrobia Hartman des côtes de France. Ann Parasitol Hum Comp 53:577-593

> Deblock S (1980) Inventaire des trématodes larvaires parasites des mollusques Hydrobia (Prosobranches) des côtes de France. Parassitologia 22:1-105

Fredensborg BL, Mouritsen KN, Poulin R (2005) Impact of trematodes on host survival and population density in the intertidal gastropod Zeacumantus subcarinatus. Mar Ecol Prog Ser 290:109-117

Fredensborg BL, Mouritsen KN, Poulin R (2006) Relating bird host distribution and spatial heterogeneity in trematode. Mar Biol 149:275-283

Fretter V, Graham A (1994) British prosobranch molluscs: their functional anatomy and ecology. Ray Society, London

Fried B, Eyster LS, Pechenik JA (1998) Histochemical glycogen and neutral lipid in Echinostoma trivolvis cercariae and effects of exogenous glucose on cercarial longevity. J Helminthol 72:83-85

Galaktionov KV, Dobrovolskij AA (2003) The biology and evolution of trematodes: an essay on the biology, morphology, life cycles, transmission, and evolution of digenetic trematodes. Kluwer Academic Publishers, Boston, MA

> Hechinger RF, Lafferty KD, Mancini FT III, Warner RR, Kuris AM (2008) How large is the hand in the puppet? Ecological and evolutionary factors affecting body mass of 15 trematode parasitic castrators in their snail host. Evol Ecol (in press) doi:10.1007/s10682-008-9262-4

Huspeni TC, Lafferty KD (2004) Using larval trematodes that parasitize snails to evaluate a saltmarsh restoration project. Ecol Appl 14:795-804

Kaplan AT, Halling S, Lafferty KD, Kuris AM (in press) Small estuarine fishes feed on large trematode cercariae: lab and field investigations. J Parasitol

Køie, M (1975) On the morphology and life-history of Opechona bacillaris (Molin, 1859) Loos, 1907 (Trematoda, Lepocreadiidae). Ophelia 13:63-86

Kuris AM, Hechinger RF, Shaw JC, Whitney KL and others (2008) Parasite and free-living biomass in estuaries: implications for ecosystem energetics. Nature 454:515-518

Lafferty KD, Dobson AP, Kuris AM (2006a) Parasites dominate food web links. Proc Natl Acad Sci USA 103: 11211-11216

Lafferty KD, Hechinger RF, Shaw JC, Whitney K, Kuris AM (2006b) Food webs and parasites in a salt marsh ecosystem. In: Collinge S, Ray C (eds) Disease ecology: community structure and pathogen dynamics. Oxford University Press, Oxford, p 119-134

> Lafferty KD, Allesina S, Arim M, Briggs CJ and others (2008) Parasites in food webs: the ultimate missing links. Ecol Lett 11:533-546

Lauckner G (1980) Diseases of Mollusca: Gastropoda. In: Kinne O (ed) Diseases of marine animals, Vol I. General aspects, protozoa to gastropoda. Wiley, New York, p 311-424

- Loker ES (1983) A comparative study of the life-histories of mammalian schistosomes. Parasitology 87:343-369

McCarthy HO, Fitzpatrick S, Irwin SWB (2002) Life history and life cycles: production and behaviour of trematode cercariae in relation to host exploitation and next-host characteristics. J Parasitol 88:910-918

Mouritsen KN, Jensen KT (1994) The enigma of gigantism: the effect of larval trematodes on growth, fecundity, egestion and locomotion in Hydrobia ulvae (Pennant) (Gastropoda: Prosobranchia). J Exp Mar Biol Ecol 181:53-66

> Mouritsen KN, Poulin R (2002) Parasitism, community structure and biodiversity in intertidal ecosystems. Parasitology 124:S101-S117

Mouritsen KN, Poulin R (2003) The mud flat anemone-cockle association: Mutualism in the intertidal zone? Oecologia 135:131-137

Newell RC (1979) Biology of intertidal animals. Marine Ecological Surveys, Faversham

Nybakken JW, Bertness MD (2005) Marine biology: an ecological approach. Pearson/Benjamin Cummings, San Francisco, CA

Postel L, Fock H, Hagen W (2000) Biomass and abundance. In: Harris RP, Wiebe PH, Lenz J, Skoldal HR, Huntley M 
(eds) ICES zooplankton methodology manual. Academic Press, San Diego, CA p 83-192

Poulin R (1995) Clutch size and egg size in free-living and parasitic copepods: a comparative analysis. Evolution 49: 325-336

Poulin R (2006) Global warming and temperature-mediated increases in cercarial emergence in trematode parasites. Parasitology 132:143-151

Poulin R (2007) Evolutionary ecology of parasites. Princeton University Press, Princeton, NJ

Poulin R, Mouritsen KN (2003) Large-scale determinants of trematode infections in intertidal gastropods. Mar Ecol Prog Ser 254:187-198

Raffaelli DG, Hawkins SJ (1996) Intertidal ecology. Chapman \& Hall, London

Ricciardi A, Bourget E (1999) Global patterns of macroinvertebrate biomass in marine intertidal communities. Mar Ecol Prog Ser 185:21-35

Salonen K, Sarvala J, Hakala I, Viljanen ML (1976) The relation of energy and organic carbon in aquatic invertebrates. Limnol Oceanogr 21:724-730

Shaw RG, Mitchell-Olds T (1993) ANOVA for unbalanced

Editorial responsibility: Benni Hansen,

Roskilde, Denmark data: an overview. Ecology 74:1638-1645

Thieltges DW, Rick J (2006) Effect of temperature on emergence, survival and infectivity of cercariae of the marine trematode Renicola roscovita (Digenea: Renicolidae). Dis Aquat Org 73:63-68

Thieltges DW, Jensen KT, Poulin R (2008a) The role of biotic factors in the transmission of free-living endohelminth stages. Parasitology 135:407-426

Thieltges DW, Donas-Botto Bordalo M, Cabalero Hernández A, Prinz K, Jensen KT (2008b) Ambient fauna impairs parasite transmission in a marine parasite-host system. Parasitology 135:1111-1116

Thomas F, Renaud F, Guegan JF (2005) Parasitism and ecosystems. Oxford University Press, Oxford

Thompson RM, Mouritsen KN, Poulin R (2005) Importance of parasites and their life cycle characteristics in determining the structure of a large marine food web. J Anim Ecol 74: $77-85$

Xu X, Stack RJ, Rao N, Caulfield JP (1994) Schistosoma mansoni: fractionation and characterization of the glycocalyx and glycogen-like material from cercariae. Exp Parasitol 79:399-409

Submitted: May 14, 2008; Accepted: August 18, 2008 Proofs received from author(s): December 3, 2008 